\title{
PERANAN ISTRI DALAM MENINGKATKAN PENDAPATAN RUMAH TANGGA PETANI DI KELURAHAN PANCAITANA KABUPATEN BONE SULAWESI SELATAN
}

\author{
Wahyuni Arifda ${ }^{1}$
}

\begin{abstract}
${ }^{1}$ Alumni Pendidikaan Geografi FKIP UHO
Abstrak: Penelitian ini bertujuan untuk mengetahui apakah pekerjaan istri petani dalam meningkatkan pendapatan rumah tangga di Kelurahan Pancaitana Kabupaten Bone Sulawesi Selatan dan Bagaimana Peranan Istri Dalam Meningkatkan Pendapatan Rumah Tangga Petani.Penelitian ini dilaksanakan di Kelurahan Pancaitana Kabupaten Bone Sulawesi Selatan dengan jumlah sampel sebanyak 40 informan.Metode penelitian menggunakan metode kualitatif.Peneliti mengambil data dengan teknik wawancara dan studi dokumentasi.Pemilihan sampel dengan menggunakan teknik purposive sampling yaitu teknik penentuan sampel dengan pertimbangan tertentu. Hasil penelitian ini menunjukan adanya peranan istri petani didalam meningkatkan pendapatan rumah tangga di Kelurahan Pancaiana Kecematan Salomekko Kabupaten Bone Sulawesi Selatan,dengan menjadi pedagang, tukang jahit, buruh tani dan lain-lain. Kontribusi istri di dalam rumah tangga terlihat jelas Baik secara langsung maupun tidak langsung istri petani mempunyai peranan atau kontribusi yang besar yaitu sebesar 69,53\%, semangat para istri bekerja sangat besar walaupun dengan penghasilan yang kecil para istri petani telah ikut ambil bagian dalam menambah pendapatan keluarga dengan melakukan pekerjaan di luar kegiatan rumah tangga untuk membantu suami. Dengan bekerjanya istri secara otomatis peran nya menjadi ganda, yaitu menjadi ibu rumah tangga dan sebagai istri yang bekerja.
\end{abstract}

Kata Kunci: Peranan, Istri, Petani, Pendapatan 


\title{
ROLE OF WIFE IN INCREASING HOUSEHOLD INCOME OF FARMERS IN PANCAITANA SUB-DISTRICT OF BONE REGENCY OF SOUTH SULAWESI
}

\author{
Wahyuni Arifda ${ }^{1}$ \\ ${ }^{1}$ Geography Educational Alumni Halu Oleo University
}

\begin{abstract}
Abtract: has conducted a research entitled "Role of Wife In Increasing Household Income of Farmers in Pancaitana Sub-district of Bone Regency of South Sulawesi". Department of Geography Education, Halu Oleo University. This study aims to determine whether the work of the wife of farmers in increasing household income in Pancaitana Village Bone Regency South Sulawesi and How Role Wife In Increasing Household Income Farmers. This research was conducted in Pancaitana Village of Bone Regency of South Sulawesi with total of 40 informants. The research method used qualitative method. Researchers took data with interview techniques and documentation studies. Sample selection by using purposive sampling technique that is sample determination technique with certain consideration. The results of this study indicate the role of the wife of farmers in increasing household income in Pancaiana Sub-District of Kecamatan Salomekko Bone District South Sulawesi, by becoming traders, tailors, farm workers and others. The contribution of the wife in the household is clearly visible Both directly and indirectly the wife of the farmer has a big role or contribution that is equal to $69,53 \%$, the spirit of the wife works very big although with the small income the farmer's wife has taken part in increasing income family by doing work outside of household activities to help the husband. With the wife's work automatically her role becomes double, that is becoming a housewife and as a working wife.
\end{abstract}

Keywords: Role, Wife, Farmer, Revenue

\section{PENDAHULUAN}

Keluarga merupakan kesatuan masyarakat yang terkecil, yang terdiri dari ayah, ibu dan anak-anaknya (keluarga inti/batih).Pada umumnya sebuah keluarga tersusun dari orangorang yang saling berhubungan darah dan atau perkawinan meskipun tidak selalu.Saling berbagi atap (rumah), meja makan, makanan, uang, bahkan emosi, dapat menjadi faktor untuk mendefinisikan sekelompok orang sebagai suatu keluarga (Abdullah, 1997:140).Adapun lembaga perkawinan, sebagai sarana pembentuk keluarga adalah lembaga yang paling bertahan dan digemari seumur kehadiran masyarakat manusia.Berdasarkan definisi diatas suatu keluarga terbentuk melalui perkawinan, yaitu ikatan lahir batin seorang pria dengan seorang wanita sebagai suami istri dengan tujuan untuk membentuk keluarga yang bahagia, kekal sejahtera.

Pada dasarnya bagi wanita Indonesia, khususnya yang tinggal di daerah tertinggal dan perekonomian miskin peran ganda bukanlah sesuatu yang baru.Bagi wanita golongan ini peran ganda telah ditanamkan oleh para orang tua sejak masih berusia muda, para remaja putri tidak dapat bermain secara bebas seperti layaknya 
remaja lainnya karena terbebani kewajiban bekerja untuk membantu perekonomian keluarga (Soetrisno, 1997).

Pembagian kerja antara ayah dan ibu, ayah memiliki areal pekerja publik karena kedudukannya sebagai pencari nafkah utama didalam keluarga, sedangkan ibu memiliki areal pekerja domestik yang dapat diartikan oleh sebagian masyarakat yang menyatakan secara sinis bahwa seorang ibu hanya sekedar wanita yang memiliki tiga fungsi yaitu memasak, malahirkan anak, berhias, atau hanya memiliki tugas dapur, dan kasur (Notopuro, 1984 : 51).

Faktor sosial budaya yang dikemukakan diatas kadangkala menjadi penghalang ruang gerak bagi istri, akibatnya kesempatan bagi kaum ibu didalam dunia bisnis tidak mendapat kepercayaan dari masyarakat.Dengan tidak adanya kepercayaan dari masyarakat terhadap kesempatan bagi kaum ibu didalam dunia bisnis, pada akhirnya membuat kaum ibu sulit untuk mengaktualisasikan dirinya didalam masyarakat terutama didalam area pekerja publik. Berdasarkan struktur sosok wanita yang dikonsepkan oleh faktor sosial diatas maka kita akan di pertanyakan mengapa wanita mendapatkan fungsi rumah tangga atau pekerja domestik? Pemberian fungsi rumah tangga bagi peran perempuan harus melahirkan.Ini adalah fungsi yang diberikan alam kepada mereka dan fungsi ini tidak dapat diubah.

Keterlibatan perempuan atau istri dalam melakukan peran ganda merupakan perilaku atau tindakan sosial yang diharapakan dapat menciptakan stabilitas dan harmoni keluarga.Ibu - ibu dari keluarga yang berpenghasilan rendah, umumnya melakukan peran ganda karena tuntutan kebutuhan hidup bagi keluarga.Meskipun suami berkewajiban sebagai pencari nafkah yang utama dalam keluaraga, hal ini tidak menutup kemungkinan bagi istri untuk bekerja sebagai penambah penghasilan keluarga dan tentunya untuk bertujuan mencapai tingkat kesejahteraan. Para ibu lebih banyak melakukan pekerjaan-pekerjaan yang bersifat informal seperti berdagang, menjadi pembantu rumah tangga dan lain sebagainya dalam upaya mencari nafkah tambahan bagi keluarga.

Rumah tangga petani adalah salah satu contoh nyata dari keluarga yang perekonomiannya rendah didalam masyarakat.Rumah tangga petani sudah lama diketahui tergolong miskin, selain rumah tangga nelayan, buruh tani dan pengrajin (Sayogya, 1978: 1991).

Sulawesi selatan dikenal sebagai daerah yang mayoritas mata pencaharian penduduknya bercocok tanam atau bertani selain dari nelayan dan lain - lainnya. Sebagaian besar pertanian yang ada di Sulawesi selatan dikelola oleh masyarakat perdesaan. Sama halnya dengan daerah kabupaten bone Sulawesi selatan, dalam struktur perekonomian nya sektor pertanian masih menjadi sektor yang paling dominan, selain itu sektor ini masih menyerap jumlah tenaga kerja yang besar pula, karena masih banyak penduduk kabupaten bone yang menggantungkan hidupnya melalui usaha pertanian.

Istri petani ternyata memiliki peranan yang penting dalam 
menyiasati serta mengatasi kemiskinan yang dialaminya dan dalam menambah pendapatan keluarganya. Masyarakat di kelurahan Pancaitana Kecematan Salomekko Kab.Bone adalah salah satu bukti nyata yang ada didalam masyarakat mengenai peranan kaum perempuan pada masyarakat petani dalam upaya meningkatkan kesejahteraan rumah tangganya. Sebagai salah satu kelurahan yang terletak jauh dari keramaian Kota Watampone, berjarak $61 \mathrm{~km}$ dari kota pusat kota. dengan jumlah petani berjumlah sekitar \pm 559 KK. mata pencaharian masyarakat di Kelurahan Pancaitana adalah hampir seluruhnya berprofesi sebagai petani. Sebagian besar sebagai pemilik lahan dan pekerja.

Masyarakat di Kelurahan Pancaitana sebagai masyarakat petani didalam kehidupan sehari-hari memiliki permasalahan yang sama dengan masyarakat lainnya. Kemiskinan adalah salah satu masalah yang dihadapi masyarakat petani di Kelurahan Pancaitana ketidak berdayaan mereka dalam faktor ekonomi didalam kehidupan seharihari diakibatkan oleh penghasilan yang tidak menentu dan cenderung kecil dan mereka tidak bisa pergi bertani setiap hari karena faktor cuaca atau musim dan sebagainya.

Penelitian ini bertujuan untuk mengetahui bagaiamana peranan istri, untuk mengetahui berapa besar kontribusi istri dalam meningkatkan pendapatan rumah tangga petani di kelurahan pancaitana kecematan salomekko kabupaten bone Sulawesi selatan.

Kata peran dan peranan dalam sosiologi sering dianggap sama karena tidak ada pembatasan secara jelas antara peran dan peranan hanya pada sudah atau tidaknya sebuah peran itu dijalankan. Menurut Soekanto (1992:102) peran adalah segala sesuatu oleh seseorang atau kelompok orang dalam melakukan suatu kegiatan karena kedudukan yang dimilikinya. Sedangkan menurut Berry dan Suparlan (dalam Soekanto,1992:105) peranan adalah seperangkat harapan yang dikenakan pada masyarakat yang menempati kedudukan sosial tertentu. Manusia sebagai makhluk sosial memiliki kecenderungan untuk hidup berkelompok.

Kaum wanita memiliki peranan yang berupa peran wanita sebagai ibu, sebagai istri, sebagai individu wanita, dan sebagai anggota masyarakat. Setiap unsur peran yang dimiliki memerlukan tanggung jawab yang berbeda dengan peran dirinya sebagai anggota masyarakat, dan akan berbeda pula dengan peran dirinya sebagai individu. Meskipun demikian masing-masing unsur tersebut tidak boleh saling bertentangan (Sujarwa, 2001).

Peran wanita setelah perkawinan adalah melahirkan, dimana peran ini dinamakan peran reproduktif.Peran ini memang tidak bisa diganti oleh laki-laki karena memang sifatnya kodrati, dan tidak bisa dihindari.Disamping melahirkan, wanita secara tradisional harus melakukan pekerjaan rumah tangga seperti memasak, mencuci, membersihkan rumah, menjaga rumah, mengasuh anak, dan mempersiapkan keperluan keluarga sehari-hari (Handayani, 2008).

Keluarga adalah kumpulan dua orang atau lebih yang hidup bersama dengan keterikatan aturan, emosional 
dan individu mempunyai peran masing-masing yang merupakan bagian dari keluarga (Friedman, dalam Khairuddin 2002:10). Keluarga adalah unit terkecil dari masyarakat yang terdiri dari suami istri dan anaknya, atau ayah dan anaknya, atau ibu dan anaknya (Soekanto,2004:12). Menurut Pujosuwarno (1994:11), keluarga adalah suatu ikatan persekutuan hidup atas dasar perkawinan antara orang dewasa yang berlainan jenis yang hidup bersama atau seorang laki-laki atau seorang perempuan yang sudah sendirian dengan atau tanpa anakanak, baik anaknya sendiri atau adopsi, dan tinggal dalam sebuah rumah tangga. Dari ketiga pendapat diatas dapat disimpulkan bahwa keluarga merupakan dua individu yang membentuk kelompok kecil melalui ikatan perkawinan yang sah dan mengharapkan adanya keturunan serta melakukan pemenuhan-pemenuhan kebutuhan hidup.

Menurut Sajogyo (1985) istri
berusaha memperoleh (bekerja)
disebabkan adanya kemauan ibu untuk
mandiri dalam bidang ekonomi yaitu
berusaha membiayai kebutuhan
hidupnya dan bagi kebutuhan orang
lain yang menjadi tanggungannya
dengan penghasilan sendiri. Adanya
kebutuhan untuk menambah
penghasilan keluarga, dikarenakan
pendapatan suami yang rendah dan
tuntutan kebutuhan yang tinggi,
kemngkinan lain makin luasnya
kesempatan kerja yang bisa menyerap
tenaga kerja wanita antara lain
tumbuhnya kerajinan tangan dan
industri lainya yang dilakukan oleh
kaum wanita.

Menurut Esmara (1986) alasan utama yang menyebabkan tingkat pendidikan mempengaruhi tingkat pendapatan yaitu tingkat pendidikan akan mempengaruhi suatu produktifitas, baik secara langsung. Sebagai akibat dari perubahan pengetahuan dan keterampilan, dan dengan tingkat pendidikan yang sudah tinggi akan terbuka harapan yang luas. Hubungan pendidikan dalam tertentu dapat berfungsi sebagai penyalur tenaga kerja.

Gaya hidup menurut Kotler 2002 (dalam Setriyaningsih 2012) adalah pola hidup seseorang di dunia yang diekspresikan dalam aktivitas, minat, dan opininya.Gaya hidup menggambarkan keseluruhan diri seseorang dalam berinteraksi dengan lingkungannya. Pendapat ini menunjukkan bahwa gaya hidup menunjukkan karakter seseorang yang dibentuk melalui pola interaksi dengan masyaraka secara umum.

Pendapatan adalah pengahasilan yang diterima oleh para anggota masyarakat dalam waktu tertentu sebagai balas jasa atas faktorfaktor produksi nasional.( Soedyono 1992 )

Menurut Benowidjojo (1983) pertanian adalah mengusahakan tanaman dan hewan guna memenuhi kebutuhan pertanian, dalam arti luas meliputi semua kegiatan usaha dalam reproduksi flora dan fauna yang dibedakan ke dalam beberapa sektor, yaitu pertanian rakyat, perkebunan, perternakan, perikanan.

\section{METODE PENELITIAN}


Jenis penelitian ini adalah penelitian deskriptif kualitatif, dengan pendekatan studi kasus (case study).Pendekatan studi kasus merupakan suatu metode penyelidikan secara langsung dengan latar yang alamiah dan memusatkan perhatian pada suatu peristiwa secara intensif dan rinci.

Penelitian ini dilaksanakan pada awal bulan April sampai selesai tahun 2018.Adapun lokasi penelitian yang penulis adalah di Kelurahan Pancaitana Kecamatan Salomekko Kabupaten Bone, karena penulis berasal dari kelurahan tersebut, sebagai suatu kelurahan dengan corak kehidupan masyarakatnya sebagian besar petani.Dipilihnya masyarakat petani sudah mempunyai peran penting dalam meningkatkan pendapatan rumah tangganya dan peranan penting dalam pembangunan.

Informan penelitian yang di pilih secara purposive sampling yaitu teknik penarikan sampel secara subyektif dengan maksud atau tujuan tertentu, yang mana menganggap bahwa informan yang diambil tersebut memiliki informasi yang diperlukan bagi siapa saja dan peneliti yang menurut Ferdinand (2006:195). Metode pengambilan sampel yang digunakan dalam penelitian ini adalah purposive sampling yakni teknik pemilihan informasi yang dilakukan serta di pilih berdasarkan pertimbangan tertentu, oleh karena itu sampel di tentukan dengan purposive (sengaja) sehingga sampel penelitian tidak perlu mewakili populasi, tetapi lebih kepada kemampuan sampel (informan) untuk memberikan informasi selengkap mungkin kepada peneliti. Peneliti melakukan wawancara dengan Bapak Baharuddin dan 40 informan selaku istri petani.

Dalam penelitian ini data yang digunakan meliputi dua jenis data, yaitu data primer, dan data sekunder.

teknik pengumpulan data yang digunakan dalam penelitian. Namun, untuk mendapatkan data yang diperlukan dalam penelitian ini penulis hanya menggunakan beberapa teknik pengumpulan data saja, yaitu melalui wawancara sebagai sumber informasi utama dan dokumentasi sebagai informasi pelengkap.

Untuk teknik analisa data yang di gunakan dalam penelitian ini adalah dengan mengunakan kualitatif deskriptif melalui persentase berikut :

$\mathrm{P}=\mathrm{F} / \mathrm{N} \times 100 \%$

(Mukhtar Ema Widodo, 2000)

\section{GAMBARAN UMUM LOKASI PENELITIAN}

Kelurahan Pancaitana terletak di kecamatan salomekko, letaknya tepat pada pusat pemerintahan kecamatan salomekko kabupaten bone dan memiliki luas wilayah $\pm 948 \mathrm{~km}^{2}$, dan memiliki jarak tempuh $\pm 61 \mathrm{~km}$ dari pusat pemerintahan kabupaten bone. Kelurahan Pancaitana terdiri dari Empat dusun yaitu dusun Pancaitana, Dusun Timpalaja, Dusun TangkaTangka dan dusun Karamae.

\section{Jumlah Penduduk}

Jumlah penduduk kelurahan pancaitana pada tahun 2017 sebanyak 2.258 jiwa.Jumlah penduduk jenis kelamin laki - laki sebanyak 1.107 jiwa dan jumlah penduduk jenis 
kelamin perempuan 1.151 jiwa. Pancaitana dapat di lihat pada tabel 3.1 Jumlah penduduk di Kelurahan

Tabel 3.1

Jumlah Penduduk di Kelurahan Pancaitana Kecematan Salomekko, tahun 2017

\begin{tabular}{rlcccc}
\hline No & Nama Dusun & Laki - laki & Perempuan & $\begin{array}{c}\text { Jumlah } \\
\text { Jiwa }\end{array}$ & $\begin{array}{c}\text { Jumlah } \\
\text { KK }\end{array}$ \\
\hline 1. & Pancaitana & 270 & 275 & 545 & 107 \\
2. & Timpalaja & 147 & 155 & 300 & 100 \\
3. & Tangka & 332 & 347 & 679 & 145 \\
4. & Karamae & 358 & 374 & 732 & 207 \\
\hline & Jumlah & 1.107 & 1.151 & 2.258 & 559 \\
\hline
\end{tabular}

Sumber : Database Kelurahan Pancaitana 2018

Tabel 3.1 menunjukan di dusu Pancaitana terdapat $107 \mathrm{KK}$ dengan jumlah jiwa sebanyak 545 jiwa, dusun Timpalaja terdapat $100 \mathrm{KK}$ dengan jumlah jiwa sebanyak 300 jiwa, dusun Tangka - tangka terdapat $145 \mathrm{KK}$ dengan jumlah jiwa sebanyak 679 jiwa, dan dusun Karamae terdapat 207 KK dengan jumlah jiwa sebanyak 732 jiwa. Penduduk kelurahan pancaitana mayoritas suku bugis, dimana masyarakat tersebut masih kental dengan adat istiadat yang turun temurun masih melekat hingga saat ini.

\section{Keadaan Penduduk Berdasarkan Tingkat Pendidikan}

Tingkat pendidikan di Kelurahan Pancaitana pada umumnya berbeda - beda sehingga keterampilan, sikap, dan tindakan yang dapat di lakukan dalam setiap usaha penduduknya sangat berpengaruh. Hal tersebut disebabkan kurangnya kesadaran masyarakat akan pentingnya pendidikan, dan faktor ekonomi yang menjadi penyebab utamanya yang menghambat dalam pendidikan. Untuk lebih jelasnya tingkat pendidikan penduduk kelurahan pancaitana dapat dilihat pada tabel 3.2.

Tabel 3.2

Tingkat pendidikan penduduk di kelurahan pancaitana kecematan salomekko, 2017

\begin{tabular}{clcc}
\hline No & Tingakat pendidikan & Jumlah jiwa & Persentase (\%) \\
\hline 1. & Belum sekolah & 200 & $9 \%$ \\
2. & Tidak tamat SD & 188 & $8 \%$ \\
3. & Tamat SD & 285 & $13 \%$ \\
4. & Tamat SMP & 700 & $31 \%$ \\
5. & Tamat SMA & 587 & $26 \%$ \\
6. & Tamat Perguruan Tinggi & 298 & $13 \%$ \\
\hline \multicolumn{2}{c}{ Jumlah } & 2.258 & $100 \%$
\end{tabular}

Sumsumsumber : data base kelurahan pancaitana 2018 
Pada tabel 3.2, menunjukan bahwa sebagian besar penduduk di kelurahan pancaitana belum sekolah yaitu sebanyak 9\%, tidak tamat SD yaitu sebanyak 8\%, tamat SD sebanyak 13\%, tamat SMP sebanyak $31 \%$, tamat SMA sebanyak $26 \%$, dan tamat Perguruan Tinggi yaitu sebanyak 13\%. Dengan demikian berarti sumber daya manusia di di kelurahan pancaitana sudah cukup memadai.

\section{Keadaan Penduduk Berdarkan Mata Pencaharian}

Penduduk di kelurahan pancaitana pada umumnya bekerja pada sector pertanian, sebagai masyarakat yang banyak menggantungkan hidupnya dari mata pencaharian sebagai petani. penduduk yang berdomisili di kelurahan pancaitana tersebut, mempunyai mata pencaharian yang beragam, diantaranya sebagai Pegawai Negeri Sipil (PNS), petani, peternak sapi, buruh tani, pedagang, tukang jahit dan lain-lain. Keseluruhan mata pencaharian ini berjalan sebagai rutunitas sehari hari guna memenuhi kebutuhan hidup keluarganya masingmasing.

Mata pencaharian yang digeluti oleh masing-masing penduduk kelurahan pancaitana, terkadang bukan sebagai mata pencaharian pokok atau terfokus pada pekerjaan itu saja, tetapi ada banyak pendapatan yang dilakukan penduduk, yang disebut sebagai mata pencaharian sampingan dan dilakukan dengan sesuai keahlian masing-masing dan kemampuannya untuk menambah pendapatan dalam keluarga. Berikut ini merupakan jumlah penduduk berdasarkan mata pencaharian sebagai berukut:

Tabel 3.3

Jumlah Penduduk Kelurahan Pancaitana berdasarkan pekerjaan ( usia 10 tahun ke atas)

\begin{tabular}{cccc}
\hline No & Jenis mata pencaharian & Jumlah ( jiwa ) & Keterangan \\
\hline 1. & Petani & 515 & \\
2 & Tukang jahit & 10 & \\
3 & Pedagang & 56 & \\
4 & PNS & 174 & \\
5 & Karyawan perusahaan & 84 & \\
6 & Nelayan & 32 & \\
7 & Peternak sapi & 37 & \\
8 & Honorer & 170 & \\
9. & Buruh/tenaga lepas & 894 & \\
10. & Pensiunan & 230 & 56 \\
11 & Tidak bekerja & 50
\end{tabular}

Sumber Data Base Kelurahan Pancaitan 2018

Jumlah Usia Penduduk Kelurahan Pancaitana

Penduduk kelurahan pancaitana memiliki jumlah penduduk secara keseluruhan sebanyak 2.258 jiwa yang terdiri dari beberapa tingkat usia mulai dari usia 0 - 4 tahun sampai 65>. Lebih jelasnya jumlah penduduk kelurahan pancaitana menurut usia dapat dilihat pada tabel 3.4. 
Tabel 3.4

Keadaan penduduk Kelurahan Pancaitana berdasarkan tingkat usia 2017

\begin{tabular}{cccc}
\hline No & Usia & Jumlah jiwa & Persentase (\%) \\
\hline 1. & $0-4$ & 158 & $7 \%$ \\
2. & $5-9$ & 188 & $8.3 \%$ \\
3. & $10-14$ & 225 & $10 \%$ \\
4. & $15-19$ & 225 & $10 \%$ \\
5. & $20-24$ & 211 & $9.3 \%$ \\
6. & $25-29$ & 185 & $8.1 \%$ \\
7. & $30-34$ & 158 & $6.1 \%$ \\
8. & $35-39$ & 156 & $7 \%$ \\
9. & $40-44$ & 145 & $6.4 \%$ \\
10. & $45-49$ & 147 & $7 \%$ \\
11. & $50-54$ & 109 & $5 \%$ \\
12. & $55-59$ & 100 & $4.4 \%$ \\
13. & $60-64$ & 77 & $3.4 \%$ \\
14 & $65>$ & 173 & $8 \%$ \\
\hline \multicolumn{5}{r}{} & Jumlah & 2.258 & $100 \%$
\end{tabular}

Sumber : Database Kelurahan Pancaitana 2018

\section{HASIL PENELITIAN}

$\underset{\text { peranan }}{\text { Kajian istri petani }} \begin{array}{r}\text { ilmiah } \\ \text { dalam }\end{array}$ meningkatakan pendapatan rumah tangga di Kelurahan Pancaitana Kecematan Salomekko Kabupaten Bone menggunakan metode penelitian kualitatif dengan tujuan agar dapat memahami fenomena yang dialami oleh subjek penelitian.Dengan teknik purposive sampling, maka responden dalam penelitian itu berjumlah dua belas orang istri petani.

\section{Gambaran Kelurahan Pancaitana Kecematan Salomekko}

Sebagaimana di ketahui bahwa daerah kabupaten bone merupakan daerah yang mayoritas penduduknya bertani dan kecematan salomekko, kelurahan pancaitana merupakan salah satu daerah pertanian yang ada di kabupaten bone bagian selatan dan penduduknya hampir semua bermata pencaharian sebagai petani.

\section{Gambaran Bagaimana Peranan Istri Dalam Meningkatkan. Pendapatan Rumah Tangga Petani}

Untuk lebih jelasnya berikut ini bagaimana peranan istri petani dalam meningkatkan pendapatan rumah tangga.

Dari hasil penelitian dapat diketahui bahwa para istri petani mempunyai pekerjaan sampingan dalam hal ini para istri juga berperan dalam peningkatan pendapatan keluarga selain mengurus rumah tangga dan bertani. Sebanyak 21 orang yang menjual ada yang menjual di pasar dan ada juga yang buka warung di rumahnya untuk berjualan, istri yang mempunyai pekerjaan menjahit sebanyak 4 orang, sedangkan istri yang bekerja sebagai buruh tani sebanyak 15 orang. Istri petani yang memiliki pekerjaan atau rutinitas diluar rumah ataupun yang memiliki pekerjan selain mengurus rumah tangga dan bertani tetap melakukan kegiatan di dalam rumah yang seolah 
- olah tidak mengenal waktu dalam pelaksanaannnya tugas ini berkaitan dengan mengurus anak, mendidik, mengasuh, menyiapkan makan dan minum bagi segenap anggota keluarga. Dari data diatas dapat diketahui bahwa istri bukan hanya berperan sebagai ibu rumah tangga akan tetapi juga berperan dalam menambah penghasilan keluarga.

\section{Pendapatan Istri Petani di Kelurahan Pancaitana}

Tingkat pendapatan merupakan pendapatan bersih yang diperoleh selama melakukan usaha, tingkat pendapatan dapat dilihat dari tingkat pendapatan, penerimaan, biaya yang dikeluarkan dan biaya kebutuhan hidup sehari- hari.Masing informan memiliki pendapatan yang berbedabeda. Akan tetapi para istri mempunyai pendapatan bukan hanya pendapatan dari bertani melainkan juga didapatkan dari usaha lain yang mereka lakukan.

Dari hasil penelitian menunjukan bahwa pendapatan istri petani yang mempunyai pekerjaan atau usaha sampingan mereka peroleh dari usaha yang mereka lakukan mulai dari menjual sampai menjadi buruh tani setiap informan mempunyai pekerjaan yang berbeda - beda dalam menambah pendapatan keluarga. Pendapatan para istri pun berbeda- beda mulai dari yang pendapatannya $\mathrm{Rp} 21.000 .000$ juta/bulan sampai Rp 1. 500.0000/bulan, sesuai dengan jenis pekerjaan yang mereka lakukan setiap hari.

Berdasarkan hasil penelitian maka diperoleh pendapatan bersih atau pendapatan rata- rata para istri dalam sebulan dari pekerjaan sampingan yang dilakukan yaitu. Untuk lebih jelasnya dapat dirincikan dalam tabel berikut.

Dari hasil penelitian menunjukan bahwa para istri petani yang yang bekerja di Kelurahan Pancaitana bukan hanya menambah pendapatan kelurga, akan tetapi pendapatan yang mereka peroleh digunakan dengan sebaik - baiknya untuk kebutuhan keluarga dan lainnya. Selain bekerja membantu suami dalam meningkatkan pendapatan keluraga para istri juga mengelolah dan mengatur keuangan dalam keluarga, pengeluaran dalam keluarga dikelolah mulai dari biaya kehidupan sehari- hari sampai biaya operasional dalam pekerjaan sampingan mereka dalam setiap bulan.

\section{Kontribusi atau Peranan Istri Dalam Meningkatkan Pendapatan Rumah Tangga petani}

Gambaran peranan istri dalam meningkatkan pendapatan rumah tangga di Kelurahan Pancaitana, Kabupaten Bone, Sulawesi selatan diwujudkan dalam kedua peranannya baik dalam lingkungan rumah tangga, maupun dalam masyarakat.Peranan istri dalam lingkungan rumah tangga meliputi kegiatan mulai dari mencuci, menyapu, memasak dan membersihkan rumah sampai mengurus anak.Pekerjaan ini tidak dihargai dengan uang, tetapi besar pengaruhnya terhadap pencapaian dalam meningkatkam kesejahteraan keluarga.Kegiatan ini mereka lakukan sebelum melakukan aktivitas di luar rumahnya, walaupun kegiatan ini dilakukan bersama-sama dengan anggota keluarga, namun kegiatan istri masih memiliki porsi yang cukup tinggi. 
Sebelum melakukan aktivitas dalam bidang ekonomi, istri telah menyelesaikan pekerjaan rumah tangganya, maka tidak aneh lagi jika seorang ibu bangun tidur lebih pagi dari pada suaminya.Mencuci, memasak, mengurus, membersihkan dan membereskan rumah adalah kegiatan rutin para istri sebelum mereka bekeja di luar rumah dan itu dilakukan setiap hari tanpa kenal lelah. Untuk kehidupan ekonomi yang lebih baik bagi warga kelurahan pancaitana bukan hal baru lagi apabila ayah dan ibu sama-sama merasa bertanggung jawab terhadap kelangsungan hidup rumah tangganya. Idealnya seorang suamilah yang bertanggung jawab penuh dalam memenuhi kebutuhan keluarganya, termasuk pendapatan keluarga karena ia berstatus sebagai kepala keluarga. Namun, pada kenyataannya para istri juga ikut membantu tentunya sesuai dengan kemampuan nya.Dalam hal ini istri ikut membantu meningkatkan pendapatan keluarga dan mendapat dukungan dari para suami, dikarenakan pekerjaan ini tidak menggangu tugas ibu rumah tangga, juga sebagai upaya istri untuk mendapatkan pendapatan tambahan.

Tabel4.1

Kontribusi atu peranan istri dalam meningkatkan pendapatan

\begin{tabular}{ccccc}
\hline & $\begin{array}{c}\text { Pendapatan dari } \\
\text { bertani/3 bulan }\end{array}$ & $\begin{array}{c}\text { Pendapatan } \\
\text { istri/ bulan }\end{array}$ & $\begin{array}{c}\text { Jumlah pendapatan } \\
\text { keluarga keseluruhan }\end{array}$ & $\begin{array}{c}\text { Peranan } \\
\text { istri } \\
(\%)\end{array}$ \\
\hline $\begin{array}{c}\text { Total } \\
\text { Pendapatan }\end{array}$ & 77.500 .000 & 178.000 .000 & 256.000 .000 & $69.53 \%$ \\
\hline Rata-rata/bulan & 1.937 .500 & 4.450 .000 & 6.400 .000 & $69.53 \%$ \\
\hline \multicolumn{2}{l}{ Sumber : hasil analisis penelitian(2018) }
\end{tabular}

Dari tabel diatas menunjukan bahwa kontribusi atau peran istri dalam meningkatkan pendapatan keluarga yaitu sebesar $69.53 \%$ dalam hal ini istri mempunyai peranan atau kontribusi yang cukup besar dalam peningkatan pendapatan keluarga. selain itu dapat diketahui bahwa ada peningkatan pendapatan dalam keluarga petani dengan setelah istri bekerja dan mempunyai usaha sampingan selain menjadi ibu rumah tangga dan bertani.

Jumlah Pendapatan keluarga dari hasil bertani secara keseluruhan dari 40 informan yaitu sebesar $\mathrm{Rp}$. 77.500.000 dan pendapatan istri dari pekerjaan sampingannyan dalam sebulan secara keseluruhan yaitu sebesar Rp 178.000.000 dengan jumlah pendapatan keluarga secara keseluruhan dari semua informan yaitu sebesar Rp. 256.000.000.

Rata- rata pendapatan keluarga dari bertani per sekali panen yaitu 3 bulan sekali dengan 40 informan di atas yaitu sebesar Rp 1.937.500 setelah istri bekerja atau mempunyai pekerjaan sampingan rata-rata pendapatan istri dalam sebulan yaitu sebesar Rp 4.450.000 dari pendapatan tersebut maka rata-rata Pendapatan keluarga secara keseluruhan dalam sebulan yaitu sebesar Rp 6.400 .000 ini menunjukan bahwa ada peningkatan pendapatan dalam sebulan yang cukup signifikan dari hasil pekerjaan sampingan ibu-ibu untuk menambah pemasukan keluarga selain dari hasil bertani. 
Dari hasil wawancara dengan beberapa informan istri petani yang mewakili dapat diketahui bahwa kontribusi atau peranan istri dalam meningkatkan pendapatan rumah tangga cukup besar baik itu secara langsung maupun tidak langsung istri telah ikut ambil bagian dalam membantu suami mencari nafkah untuk keluarga.

\section{PEMBAHASAN}

Konsep diri wanita tentang sosok wanita Indonesia yang ideal dalam masyarakat. Konsep diri wanita ini ditumbuh kembangkan berdasarkan corak kebudayaan nasioanal Indonesia yang ingin diwujudkan oleh Negara untuk kemajuan bersama warga Negaranya. Konsep diri wanita tidak hanya membebankan pekerjaanpekerjaan dalam lingkup domestik tetapi juga serangkaian peran yang harus dijalankan perempuan sebagai seorang istri. Peran tersebut adalah sebagai pencari nafkah tambahan sebagai warga masyarakat inilah yang sebenarnya yang terjadi pada kaum perempuan di kelurahan pancaitana.

Para istri dalam rumah tangga berperan sebagai istri pendamping suami, sebagai pengelolah rumah tangga, sebagai penerus keturunan dan pendidik. Sebagai konsekuensi dari peran-peran tersebut mereka harus mengerjakan setumpuk pekerjaan dalam rumah yang tidak memiliki batas jangka waktu kerja. Hanya pada sore dan malam hari mereka dapat bersantai dan beristirahat karena anggota keluarga lainnya juga berhenti beraktifitas.

Para istri berkewajiban melakukan pekerjaan-pekerjaan seperti menyiapkan makanan bagi seluruh anggota keluarga, memasak air, menyiapkan bekal suami, membersihkan peralatan dapur serta peralatan untuk makan yang kotor, mencuci dan menyetrika pakaian seluruh anggota keluarga, mengasuh anak, melayani suami, dan menyapu lantai. Para ibu memulai aktifitasnya sekitar jam 05.00 Wita hingga menjelang magrib atau sekitar 17.30 Wita.

Pendapatan dari istri petani yang dihasilkan dari pekerjaan dan usaha sampingan yang mereka lakukan memmpunyai dampak yang sangat besar dalam peningkatan pendapatan keluarga di Kelurahan Pancaitana dengan rata pendapatan bersih dalam sebulan Rp. 4. 450.000.

Kaum ibu di Kelurahan Pancaitana diserahkan tanggung jawab untuk mengelolah pendapatan keluarga sesuai dengan peranannya sebagai pengelolah dan pengatur rumah tangga.Para suami harus bertanggung jawab untuk mencari uangnya dan istrilah yang mengatur penggunaannya.Namun, dalam pengelolaannya istri tidak bisa sekehendak hatinya sendiri, ada pedoman-pedoman yang harus dia penuhi dalam mengatur pendapatan keluarga. Pedoman tersebut antara lain pengadaan uang kebutuhan hidup sehari-hari, pengadaan uang untuk pembekalan selama bertani, pengadaan uang untuk kepentingan kehidupan yang lain. Satu hal lagi yang harus diperhatikan oleh para istri adalah tersedianya uang tabungan keluarga yang diperuntukkan bagi kepentingan tak terduga dan untuk membangun rumah.Mereka menyerahkan semua pengahasilan yang mampumereka peroleh kepada istri tanpa 
mempedulikan bahwa cukup atau tidaknya untuk memenuhi kebutuhan sehari-hari.Keadaan ini terjadi karenapara suami beranggapan bahwahanya itu yang dapat mereka peroleh dari pekerjaan mereka sebagai petani yang harus mereka syukuri.

Dalam masyarakat di mana keluarga sebagai satuan terkecil mengalami kekurangan ekonomi, menjadi alasan kuat para wanita melakukan kegiatan peningkatan ekonomi dengan melakukan kegiatan dalam meningkatkan kesejahteraan keluarga.Inilah salah satu pendorong bagi kaum ibu untuk melakukan tindakan yang berguna dalam memenuhi kebutuhan keluarganya.Hal tersebut didesak pula oleh tidak cukupnya pula penghasilan suami dalam memenuhi kebutuhan seharisehari.Latar belakang inilah yang menjadi pendorong bagi para istri petani di Kelurahan Pancaitana untuk melaksanakan perannya sebagai pencari nafkah tambahan bagi keluarga.

Dengan bekerjanya para istri petani di Kelurahan Pancaitana menunjukan ada peningkatan pendapatan dalam rumah tangga petani setelah istri memiliki pekerjaan sampingan selain menjadi ibu rumah tangga dan mengurus anak di rumah.Dari hasil pekerjaan para istri petani tersebut di gunakan untuk memenuhi kebutuhan keluarga dan disimpan sebagian untuk keperluan lainnya seperti untuk biaya pendidikan anak mereka.

Bagi keluarga petani yang memiliki penghasilan yang lebih baik, para istri lebih banyak membuka warung di depan rumah. Mereka yang membuka warung berpendapat bahwa selain mendapatkan penghasilan yang cukup dari keuntungan warung, mereka juga tidak harus keluar rumah dan dapat mengerjakan pekerjaanpekerjaan rumah tangga.Sebagian besar dari istri petani beranggapan bahwa pekerjaan-pekerjaan rumah tangga telah banyak menyita waktu mereka sehingga lebih memilih jenisjenis pekerjaan atau usaha yang dapat dikerjakan di rumah.

Talcott Parson berpendapat bahwa sang suami mengembangkan kariernya di luar rumah, istri bekerja di dalam rumah tangganya merupakan pengaturan yang jelas yang kemungkinannya meniadakan terjadinya persaingan antara suamiistri, karena persaingan suami-istri akan merusak keserasian kehidupan perkawinan, oleh sebab itu teori ini berpendapat bahwa perempuan harus tinggal dalam kehidupan rumah tangga karena ini merupakan pengaturan yang paling baik dan berguna bagi keuntungan masyarakat secara keseluruhan (Pandu Maria, 2006 ).

Dari hasil wawancara yang telah dilakukan peneliti dengan 40 informan yang berada di Kelurahan Pancaitana, Kabupaten Bone, Sulawesi Selatan, maka dapat diperoleh informasi bahwa para istri petani memiliki peran ganda, selain berperan di sektor domestik (rumah tangga ) mereka berperan juga pada sektor publik ( di luar rumah tangga) sebagai pencari pendapatan tambahan bagi keluarganya.

Para istri petani di Kelurahan Pancaitana, Kabupaten Bone, Sulawesi Selatan menjalankan peran ini dengan cara menjadi tukang jahit, jual sayur di pasar, membuka warung di rumah, menjual pakaian dan ikan, serta 
menjadi buruh tani, walaupun sebagian besar dari mereka tidak bekerja pada orang lain, mereka telah membantu para suami meningkatkan pendapatan keluarga. Usaha mereka sebagian besar memanfaatkan apa yang menjadi sumber daya alam di sekitar mereka. Alasan mereka hanya memanfaatkan dari mengelolah apa yang sudah ada sehingga tidak perlu mengeluarkan uang secara khusus untuk membeli barang produksi karena nantinya memberatkan pengeluaran keluarga.

Posisi sebagai pencari nafkah tambahan menempatkan para kaum ibu sebagai anggota keluarga yang membantu suami dalam mencari nafkah sehingga motivasi mereka adalah membantu yang kemudian dipahami sebagai kewajiban di banding wanita untuk membantu suami mengelolah hasil panen.

Menurut Rozalinda dalam artikelnya yang berjudul peran waqaf dalam pemberdayaan ekonomi perempuan menjelaskan bahwa istri memberikan kontribusi secara ekonomi bagi keluarga manakala penghasilan dari suami tidak mencukupi atau bahkan bila suami tidak bekerja Istri yang bekerja memiliki kontribusi pada perekonomian rumah tangga keluarga dengan penghasilan yang di dapatkannya dapat menambahkan pendapatan rumah tangga dan meningkatkan kesejahteraan keluarganya.Selain itu pendapatan yang di dapatkan oleh istri juga dapat membantu dalam aspek pendidikan untuk anak-anaknya, walaupun para istri petani juga hanya mampu menyekolakan anak-anak mereka sampai jenjang SMP dan paling tinggi sekolah SMA.

\section{PENUTUP}

Berdasarkan pemaparan hasil penelitian dan pembahasan dapat di simpulkan bahwa Peranan istri dalam meningkatkan pendapatan rumah tangga petani di Kelurahan Pancaitana Kecamatan Salomekko Kabupaten Bone. Baik secara langsung maupun tidak langsung istri petani di KelurahanPancaitana yaitu 40 informan tersebut telah ikut ambil bagian dalam menambah pendapatan keluarga dan setelah istri bekerja ada peningkatan pendapatan dalam rumah tangga petani. Dalam hal ini bahwa istri bukan hanya berperan sebagai ibu rumah tangga akan tetapi juga berperan dalam meningkatkan pendapatan rumah tangga petani.

Dari 40 informan ibu - ibu semua termasuk istri yang yang aktif di luar rumah dalam hal ini semua mempunyai pekerjaan sampingan mulia menjadi pedagang, tukang jahit, sampai menjadi buruh tani untuk meningkatkan pendapatan keluarga dan membantu suami dalam memenuhi kebutuhan keluarga.

Kontribusi atau peran seorang istri dalam meningkatkan pendapatan keluarga di Kelurahan pancaitana memiliki peran yang cukup besar yaitu sebesar $69.53 \%$ dengan demikian bahwa istri di kelurahan pancaitana mempunyai peranan yang sangat membantu suami dalam menambah ataupun meningkatkan pendapatan keluarga.

Berdasarkan kesimpulan di atas maka peneliti memberikan saran sebagai berikutberikut:

1. Sebaiknya pemerintah lebih bersikap adil dalam 
memberikankesempatan kepada perempuan berkarir diluar rumah tangga dan lebih memperhatikan kaum perempuan . Adanya pengakuan dari masyarakat tentang peranan istri dalam meningkatkan pendapatan rumah tangga petani. Serta adanya langkah nyata dari berbagai pihak untuk meminimalkan diskriminasi antara laki-laki dan perempuan.

2. Sebaiknya pemerintah setempat agar mengadahkan penyuluhan atau sosialisasitentang kehidupan berumah tangga, sehingga tercipta pembagian kerja yang seimbang antara laki-laki dan perempuan.

3. Pemerintah sebaiknya membangun koperasi simpan pinjam khusus bagi para petani di Kelurahan Pancaitana agar para petani dapat lebih mudah dalam membeli alat-alat pertanian untuk kepentingan kelancaran para petani dalam bertani, koperasi tersebut harus menyediakan berbagai macam alat pertanian yang dapat dicicil pembayarannya ataupun peminjaman modal bagi petani yang ingin membuka usaha sampingan.

4. Kepada peneliti lain dapat dijadikan sumbangan pemikiran untuk mengadakan penelitian lebih lanjut yang bersifat mendalam, karena penelitian ini masih sangat jauh dari kesempurnaan.

\section{DAFTAR PUSTAKA}

Abdullah, Irawan. 1997. Sangkan Paran Gender. Yogyakarta : Pustaka Pelajar Offset

Ahmad Mudzakir dan Joko Sutrisno. 1997. Psikologi Pendidikan. Pustaka Setia. Bandung
Augusty, Ferdinand. 2006. Metode

Penelitian

Manajemen.

Semarang: Universitas

Diponegoro

Benowidjojo, M. 1983, Pembangunan Pertanian, Opini Malang dan Usaha Tani, Surabaya.

Esmara.1986, Sumber Daya Manusia, Kesempatan Kerja dan Perkembangan Ekonomi.UI Press, Jakarta.

Handayani, W dan Haribowo, A.S. 2008, "Buku Ajar Asuhan Keperawatan pada Klien dengan Gangguan Sistem Hematologi", Salemba medika, Jakarta.

Notopuro, Hardjito. 1984. Peranan wanita Dalam Masa Pembangunan di Indonesia, Ghalia Indonesia, Jakarta.

Sajogyo.1985, Lapisam yang paling lemah di pedesaan jawa.Prisma 4, Jakarta.

Sajogyo. 1978, Lapisan yang paling lemah di pedesaan Jawa. Prisma 4, Jakarta.

Setriyaningsih, Puji. 2012. Sosiologi Gaya Hidup. http://pujisetriya.blogspot.co.id /2012/12/sosiologi-gayahidup.html (diakses pada tanggal 15 maret 2018)

Soekanto, S. 1992, Memperkenalkan Sosiologi, Rajawali Press, Jakarta

Soekanto, S. 2004, Sosiologi Suatu Pengantar, Rajawali, Jakarta. 
Jurnal Penelitian Pendidikan Geografi Volume 3. No 4 Oktober 2018

Sujarwa. 2001, Polemik Gender antara Realitas dan refleksi Sebuah Kajian Sosiologi Seni, Pustaka Pelajar, Yogyakarta. 